\title{
Pollution tolerance, flight capacity and natural history explain metacommunity structure in high-altitude stream insects
}

\author{
Tolerância à poluição, capacidade de voo e história natural explicam a estrutura da
} metacomunidade em insetos de riachos de alta altitude

Mireile Reis dos Santos ${ }^{1,2 *}$ (D), Victor Satoru Saito ${ }^{3}$ (D), Paulo Augusto Zaitune Pamplin ${ }^{4}$ (D), Allan Arantes Pereira ${ }^{2}$ (D) and Alaíde Aparecida Fonseca-Gessner ${ }^{1}$

${ }^{1}$ Programa de Pós-graduaçáo em Ecologia e Recursos - PPGERN, Laboratório de Ecologia de Insetos Aquáticos, Universidade Federal de São Carlos - UFSCar, Rod. Washington Luís, Km 235, SP-310, CEP 13565-905, São Carlos, SP, Brasil

${ }^{2}$ Instituto Federal de Educaçáo, Ciência e Tecnologia do Sul de Minas Gerais - IFSULDEMINAS, Campus Poços de Caldas, Av. Dirce Pereira Rosa, 300, Jardim Esperança, CEP 37713-100, Poços de Caldas, MG, Brasil

${ }^{3}$ Departamento de Ciências Ambientais - DCAm, Universidade Federal de São Carlos - UFSCar, Rod. Washington Luís, Km 235, SP-310, CEP 13565-905, São Carlos, SP, Brasil

${ }^{4}$ Universidade Federal de Alfenas - UNIFAL, Campus Poços de Caldas, Rod. José Aurélio Vilela, 11999, BR 267, Km 533, Cidade Universitária, CEP 37715-400, Poços de Caldas, MG, Brasil *e-mail: mireile.santos@ifsuldeminas.edu.br

Cite as: Santos, M.R. et al. Pollution tolerance, flight capacity and natural history explains metacommunity structure in high-altitude stream insects. Acta Limnologica Brasiliensia, 2020, vol. 32, e20.

Abstract: Aim: To test how different taxonomic and functional groups of aquatic insects from high-altitude streams respond to environmental and spatial gradients at multiple scales in Southeast of Brazil. Methods: Specimens were collected in 26 high-altitude streams distributed over a gradient of previously defined environmental quality. The taxonomic identification was made at the genus level and the functional classification was based on traits of flight capacity and pollution tolerance compiled from specific literature. We obtained local in situ data (limnological, sediments, and organic matter), as well as calculated land use at the riparian and drainage basin scale. A variation partitioning approach was used to explain species composition based on different response matrices deconstructed by both taxonomic groups and functional traits. The explanatory matrices encompassed environmental variables at three spatial scales and spatial variables extracted from Principal Components of Neighbor Matrices analysis. A linear model was applied to verify the possible correlation between spatial and environmental components. Results: The contribution of the spatial and environmental components varied strongly between taxonomic and functional groups. For taxonomic groups, the pure environmental component was more important for Odonata and Trichoptera, while spatial variables were more important for Diptera (non-Chironomidae) and Chironomidae, Coleoptera, Ephemeroptera, Plecoptera and Megaloptera. The sensitive groups with good flight capacity showed a greater environmental signature while the tolerant groups with low flight capacity had a greater spatial signature. Moreover, the important variables for explaining community variation were from different spatial scale (local, riparian and watershed) depending either on the analyzed taxonomic or on functional groups. However, a general effect of forests was found in several groups. Conclusions: It 
is necessary to consider the joint effect of evolutionary natural history of groups, as well as their functional traits in the structuring of metacommunities, since only taxonomic resolutions may not be sufficient to detect assembly processes at multiple spatial scales.

Keywords: aquatic invertebrates; metacommunity; streams altitude; Poços de Caldas Plateau; environmental filtering.

Resumo: Objetivo: Testar como as diferenças taxonômicas e de grupos funcionais de insetos aquáticos de riachos de altitude respondem ao gradiente ambiental e espacial em múltiplas escalas no sudeste do Brasil. Métodos: As amostras foram coletadas em 26 riachos de altitude distribuídos em um gradiente de qualidade ambiental previamente definido. A identificaçấo taxonômica foi feita no nível de gênero e a classificação funcional foi baseada em características de capacidade de voo e tolerância à poluição compiladas a partir de literatura específica. Obtivemos dados locais in situ (limnológicos, sedimentos e matéria orgânica), bem como calculamos o uso da terra na zona ripária e na escala da bacia hidrográfica. O particionamento de variância foi usado para explicar a composição de espécies com base em matrizes de resposta desconstruídas por grupos taxonômicos e características funcionais. As matrizes explicativas abrangeram as variáveis ambientais em três escalas e as variáveis espaciais extraídas da análise de Componentes Principais das Matrizes Vizinhas. Um modelo linear foi aplicado para verificar a possível correlação entre componentes espaciais e ambientais. Resultados: A contribuição dos componentes espaciais e ambientais variou fortemente entre os grupos taxonômico e funcional. Para os grupos taxonômicos Odonata e Trichoptera, o componente ambiental puro foi mais importante, enquanto as variáveis espaciais foram mais importantes para Diptera (excetoChironomidae) e Chironomidae, Coleoptera, Ephemeroptera, Plecoptera and Megaloptera. Os grupos sensíveis com boa capacidade de voo apresentaram maior assinatura ambiental, enquanto os grupos tolerantes e com baixa capacidade de voo tiveram maior assinatura espacial. Além disso, as variáveis importantes para explicar a variação da comunidade foram de diferentes escalas espaciais (local, riparia e da bacia hidrográfica), dependendo dos grupos taxonômicos ou funcionais analisados, mas um efeito geral das florestas foi encontrado em vários grupos. Conclusóes: É necessário considerar o efeito conjunto da história natural evolutiva dos grupos, bem como seus traços funcionais na estruturaçâo de metacomunidades, uma vez que apenas resoluçôes taxonômicas podem não ser suficientes para detectar processos de montagem em múltiplas escalas espaciais.

Palavras-chave: invertebrados aquáticos; metacomunidade; riachos de altitude; Planalto de Poços de Caldas; filtragem ambiental.

\section{Introduction}

Metacommunities are sets of neighboring communities interconnected through dispersive processes that ensure genetic, taxonomic and composition variation among communities (Leibold et al., 2004). This perspective of open systems with flows of energy and matter allowed the researchers to have more realistic analyzes and predictions about the set of factors that drive the community structure and dynamics in nature (Finn et al., 2011). According to the metacommunity approach, both local and regional processes determine the compositional differences among communities. Communities may be dissimilar because the environment selects for different species, but also because dispersal limitation causes distant communities to be more dissimilar in species composition (Tobler, 1970). However, analyzing such processes of species sorting and dispersal limitation is challenging given that the environmental similarity itself decay along spatial distance. This would make communities to relate to both spatial and environmental factors concomitantly. In this sense, communities strongly affected by spatially structured environmental pressures would be expected to be strongly related to the spatial distance among sites as well. To disentangle the correlated effects of environmental and spatial variation on community composition, statistical techniques to partition the explained proportion of community variation were proposed (Borcard et al., 1992), becoming important tools in metacommunity studies.

Moreover, the spatial scale used will be an important element to detect ecological patterns, both related to environmental and spatial factors (Leibold et al., 2004; Heino et al., 2017; Tonkin et al., 2017a). This premise is relevant mainly in continental aquatic environments in which many streams constitute networks (Frissell et al., 1986; Finn et al., 2011; Tonkin et al., 2017b) that behave like islands disconnected by the fragmented matrix (Bilton et al., 2001; Alemu et al., 2017; Tonkin et al., 2017a). The success of colonization and persistence of aquatic insects in 
these systems may depend on factors related, not only to the environment and space, but also to the intrinsic biological characteristics of the diverse taxonomic groups inhabiting streams (Bilton et al., 2001; Poff et al., 2006; Finn et al., 2011; Saito et al., 2015a,b).

Communities of aquatic insects in streams include different clades that compose a gradient of species expected to be more or less affected by environmental and spatial variables (Vannote et al., 1980; Ter Braak \& Prentice, 1988; Allan, 2004; Allan \& Castillo, 1995). For example, the potential dispersal of aquatic insects is probably associated to their wing size (Malmqvist, 2000; Saito et al., 2015b), and groups such as large winged Odonata are potentially good fliers (Poff et al., 2006; Saito et al., 2015b), and therefore only slightly limited by sites distance, at least for small spatial extents (Tonkin et al., 2017a). On the other hand, other insects as Ephemeroptera, are potentially not good flyers (Malmqvist, 2000) and therefore more limited by the distances among streams and watersheds. In addition, some groups such as Plecoptera and Trichoptera are bounded by stream conditions (Siqueira et al., 2012; Saito et al., 2015a). Their larvae are highly sensitive to dissolved oxygen and substrate compared to other groups of insects, which are more generalist and adapted to environments with a wide range of conditions (e.g., many genera of Chironomidae).

Thus, both the environment and space can exert a selective pressure proportionally to the life history of each species. (Bilton et al., 2001; Shurin et al., 2009; Saito et al., 2015a; Heino et al., 2017; Tonkin et al., 2017a,b). The dispersive processes are not random for most groups and are composed of strategies finely adjusted to their biology and landscape scales (Padial et al., 2014). Like this, recent ecological approaches also include the functional biological traits of taxa (Reynolds et al., 2002; Finn \& Poff, 2005; Poff et al., 2006) in an attempt to use them as proxies to detect dispersive processes in metacommunities. In this way, here, we measured the relative importance of environmental and spatial components on different taxonomic and functional groups of aquatic insects metacommunities from altitude streams.

Given the reasoning above, we constructed the following hypotheses: $\mathrm{H} 1$ : the strength of the community-environment relationship (using different taxonomic and functional groups) will be positively related to the strength of the community-space relationship, meaning that, in general, community variation is driven by a spatially structured environment. H2: aquatic insects considered medium to good dispersers would respond more strongly to the environmental component than to the spatial component since these groups can disperse more easily and actively through the matrix. In contrast, taxa with lower dispersive potential would respond more acutely to the spatial component (which may be a limiting factor). And finally, H3: we expected that sensitive groups would respond strongly to the environmental component compared to tolerant taxa considering the degree of tolerance to environmental variations of different species.

\section{Material and Methods}

\subsection{Study area}

The Poços de Caldas Plateau, Minas Gerais State is an appropriate region to search for metacommunity patterns. Due to higher altitudes in the edges of the plateau than the central region, circular shape and drainage networks all internally inserted, the streams do not receive any external affluent, making it an isolated system. This characteristic would highlight internal assembly processes acting in the metacommunities, since external immigration from other basins are very unlikely, since altitudes range from 1155 to 1424 meters, but in the summit lines of the edge of the plateau these altitudes can reach up to 1700 meters (Moraes, 2007; Alberti, 2008; Moraes \& Jiménez-Rueda 2008). Aquatic invertebrate communities may be more subject to geographic isolation processes and highlight some patterns and ecological structuring processes. Thus, we limited our samples on three watersheds inserted in the Poços de Caldas Plateau, with different environmental impacts (Figure 1).

High altitudes recorded in the mountains that make up the surrounding edges of the Poços de Caldas Plateau confine the water network internally, which may promote the geographic isolation of the resident aquatic biota from the rest of the Brazilian southeast, reducing the external interferences on these communities. Because of their insularity, streams can promote greater compositional dissimilarities in the fauna, and thus highlight factors related to the functional traits of taxonomic groups, such as dispersive capacity (Finn \& Poff, 2005).

Based on the analysis of images from Google Earth (referring to the period of sampling of biological data) and validation in the field of the places where there were doubts about the typologies 

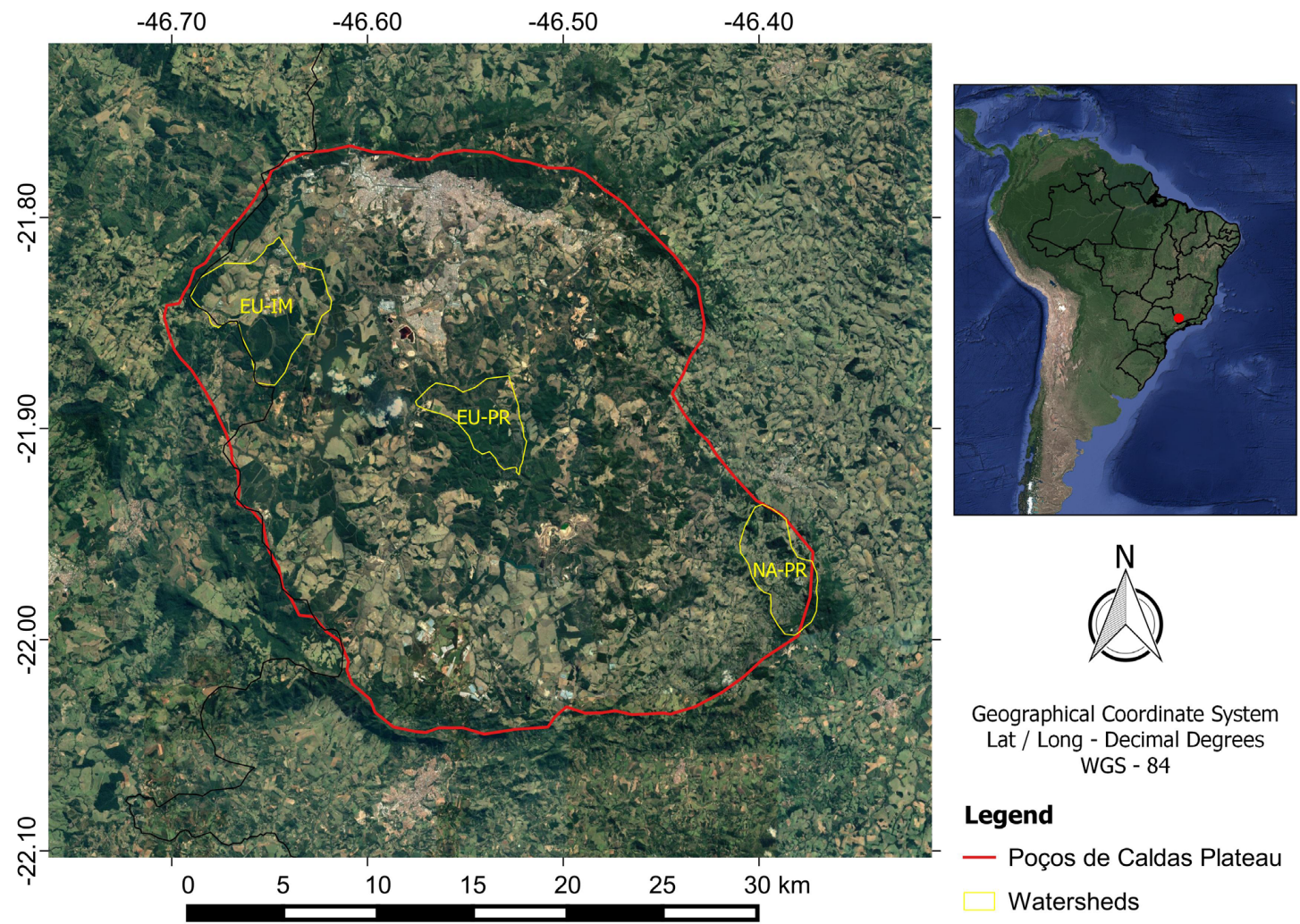

Geographical Coordinate System Lat / Long - Decimal Degrees WGS - 84

\section{Legend}

- Poços de Caldas Plateau Watersheds

Figure 1. Images of the three watersheds in the context of the Poços de Caldas Plateau - MG. Source: Google Earth Images. EU-IM (impacted eucalyptus; Amoras streams drainage basin); EU-PR (preserved eucalyptus; Moinhos stream drainage basin); NA-PR (native preserved; Verde stream drainage basin).

presented, this research was able to quantify the land uses in the three watersheds. The land use in two watersheds (EU-IM and EU-IM) was predominantly dominated by monocultures of eucalyptus, on larger scale. However, the watershed EU-PR presented evident conservation practices, such as gallery forest maintenance that occupied a large proportion of land. The watershed EU-IM is more impacted because it does not apply conservation practices like those in EU-PR. It exhibits reduced gallery forest and a large proportion of rotary crops. The watershed NA-PR has native and preserved features, being considered the one with the best environmental quality among the three with the highest percentages of native forest.

\subsection{Collection and processing of biological material}

Twenty-six low-order streams were sampled, as classified by Strahler (1957), distributed among the three watersheds, being eight streams in the EU-PR, seven streams in the EU-IM, and eleven streams in the NA-PR. In each stream, the largest variety of mesohabitats were identified in situ and aquatic invertebrates were collected in three replicate samples with a Surber and three replicate samples of twenty seconds with a $\mathrm{D}$ net (both equipment with a $250 \mu \mathrm{m}$ mesh). Taxonomic identification was made up to the genus level with the aid of taxonomic keys and specialists (Merritt \& Cummins, 1996; Epler, 2001; Benetti et al., 2003; Heckman, 2006, 2008; Lecci \& Froehlich, 2007; Mariano \& Froehlich, 2007; Michat et al., 2008; Dominguez \& Fernández, 2009; Mugnai et al., 2010; Ramírez, 2010; Springer, 2010; Froehlich, 2011; Trivinho-Strixino, 2011; Braun et al., 2014; Hamada et al., 2014). Specimens that presented loss of morphological structures were identified up to the lowest possible taxonomic level. In order to test the hypotheses, only the insects from the following orders were used: Odonata, Ephemeroptera, Plecoptera, Trichoptera, Diptera (non-Chironomidae) and Chironomidae, Hemiptera, Megaloptera, and Coleoptera.

The whole species pool was then deconstructed by species functional traits of tolerance and potential flight ability, according to Merritt \& Cummins (1996), Junqueira \& Campos (1998), Poff et al. (2006), Bilton et al. (2001) and Saito et al. (2015b) (see Supplementary Material). Taxa were separated in tolerant and resistant species and good and bad flyers. When trait categories for a given taxon were 
not found, the same trait attributed to the majority of closely related members was employed, according to Poff et al. (2006).

\subsection{Environmental variables and scales}

We defined three environmental scales to use in data analysis. The first one was composed of local limnological variables (Local Scale), the second results from land uses near streams (Riparian Scale) and the third, the watershed as a whole (Watershed Scale). The local limnological variables used were: $\mathrm{pH}$, dissolved oxygen $(\mathrm{mg} / \mathrm{L})$, temperature (degrees Celsius), electrical conductivity $(\mathrm{mS} / \mathrm{cm})$, water flow $(\mathrm{m} / \mathrm{s})$, redox potential $(\mathrm{mV})$, channel morphology, fine and coarse organic matter percentages, stream sediment granulometry, and percentages of rapids. A multiparameter probe (Horiba U52) was used to obtain these data, and the flow rate was calculated according to Wetzel $\&$ Likens (2000), both locally, in five replications, in order to ensure the minimization of random effects on the results. In order to characterize the channel, the percentage of rapids and backwaters were visually quantified according to Callisto et al. (2002). Sediment samples were collected from the streambed for further determination of grain size fractions and percentage of organic matter (Dominguez \& Fernández, 2009). To exclude the effect of rainfall on the community, they were collected during the dry season (May-August 2015).

In the Riparian Scale, the typologies of the land uses were quantified near the streams in the 100 meter buffer and the values were transformed into percentages. In the Watershed Scale, the typologies of the land uses were quantified regarding the watershed (besides quantification on the 100 meters buffer) and values were transformed into percentages. In addition, the Watershed Scale matrix also encompassed stream order and the altitude of the sampling point. This quantification of land uses in the watershed was fulfilled with the support of satellite imagery from the Google Earth software and validation of the features detected in the field, and the measured altitudes through Global Position System - GPS.

\subsection{Spatial variables}

Spatial variables were obtained by the geographical coordinates of the sampled sites and vectors were extracted using Principal Coordinates of Neighbor Matrices analysis - PCNM (Borcard \& Legendre, 2002; Borcard et al., 2004; Dray et al., 2006). Negative values were standardized by the square root. PCNM vectors represent the spatial structure in the data, where each vector describes the variation in a given spatial scale. All spatial vectors were included in subsequent analysis.

\subsection{Biological, environmental and spatial data analysis}

For the environmental characterization of watershed and their streams, a Principal Components Analysis - PCA was performed individually over the environmental variables (log transformed) grouped by Local, Riparian and Watershed Scales. Prior to analyzing biological data, we removed collinear variables with VIF higher than 5 to avoid inflating the importance of variables when modeling community response (in exception, we applied VIF cut-off of 2.5 to watershed variables since they are strongly correlate). This analysis maintained the variables $\mathrm{pH}$, temperature, redox potential, Rapids, Normal Flow, Backwater and fine sand in the Local Scale; the variables houses, short term agriculture, hydromorphic soil, exposed soil, dam, pasture, forest and altitude grassland at the Riparian Scale; and the variables altitude and stream size at the Watershed Scale. To find the strength of the community-environment relationship, a multivariate regression model was applied for direct gradient analysis (Redundancy Analysis), with a forward selection of the explanatory variables (Borcard et al., 1992, 2011). In this case a single explanatory matrix was considered using all variables (standardized) selected after VIF analysis. This model tested which variables were significant for each taxonomic and functional group individually. For this analysis, the biological dataset matrix was transformed by the Hellinger metric, as suggested by Legendre \& Gallagher (2001) and Borcard et al. (2011). After this step, to quantify the relation between community-space and community-environment, we applied a variation partitioning approach to verify the correlations between the significant environmental matrices in multiple scales (selected by forward methods) and spatial variables as proposed by Borcard et al. (1992). This process was also repeated using deconstructed taxonomic groups and species traits (potential flight ability and tolerance).

Finally, a linear regression model was applied to the results obtained after variation partitioning to verify if there was correlation between the environmental and spatial components, using the individual results for each taxonomic group analyzed. The full (pure + shared effect) Adjusted $\mathrm{R}^{2}$ of the environmental and the spatial component 
were used as explanatory and response variables in this case. A linear relationship was expected as evidence of a spatially structured environment driven community variation. The software $\mathrm{R}$ was used for all the statistical analyzes applied and the dataset tabulation: A Language and Environment for Statistical Computing (R Core Team, 2017) - Package vegan: Community Ecology Package (Oksanen et al., 2017).

\section{Results}

\subsection{Environmental gradients}

The environmental PCAs at multiple scales clearly detect the differences among watersheds but the differences varied among spatial scales (Figure 2).

For local variables and riparian variables, we noticed a clear grouping of the streams EU-IM and EU-PR drainage basins and relationship their streams with variables that indicate the presence of environmental impacts, such as the quantity of clays and silt, and high redox potential values. On the riparian scale (buffer 100 meters), these streams had a high influence of eucalyptus plantations, exposed soil, short term agriculture and dam. On the other hand, the streams NA-PR watershed were isolated from the others and presented more oxygenated and flowing waters (local scale), indicative of environments with better environmental quality (Figure 2a) and altitude grassland, forest and houses (riparian scale) (Figure 2b).
The three watersheds differed completely among themselves for land use (watershed scale) (Figure 2c). The drainage basin NA-PR was characterized mainly by altitude grassland, pasture, and mining while the EU-PR was characterized by the presence of exposed soil, eucalyptus, landfill, and higher altitude. The landscape of the EU-IM watershed was characterized by more diversified land uses with highlights on the dams, industry and houses.

\subsection{Community-environment and community-space relationships}

Variation partitioning approach detected a large variability in group responses to environmental variables and spatial vectors (Figure 3 ).

The taxa that better related to spatial vectors were Diptera (non-Chironomidae) and Chironomidae, Coleoptera, Ephemeroptera, Plecoptera and Megaloptera. The pure environmental component was more important only for Odonata and Trichoptera. Hemiptera was the taxon with lesser influenced by the two components. In relation to the biological traits analyzed, the pure environmental component was more important for sensitive groups and with good flying capacity, while the spatial component was more important for tolerant clades and with poor flying ability. Moreover, different variables from different scales were selected for different biological and functional groups (Table 1).

Limnological variables (local scale) and land use in the surroundings of streams (riparian scale)
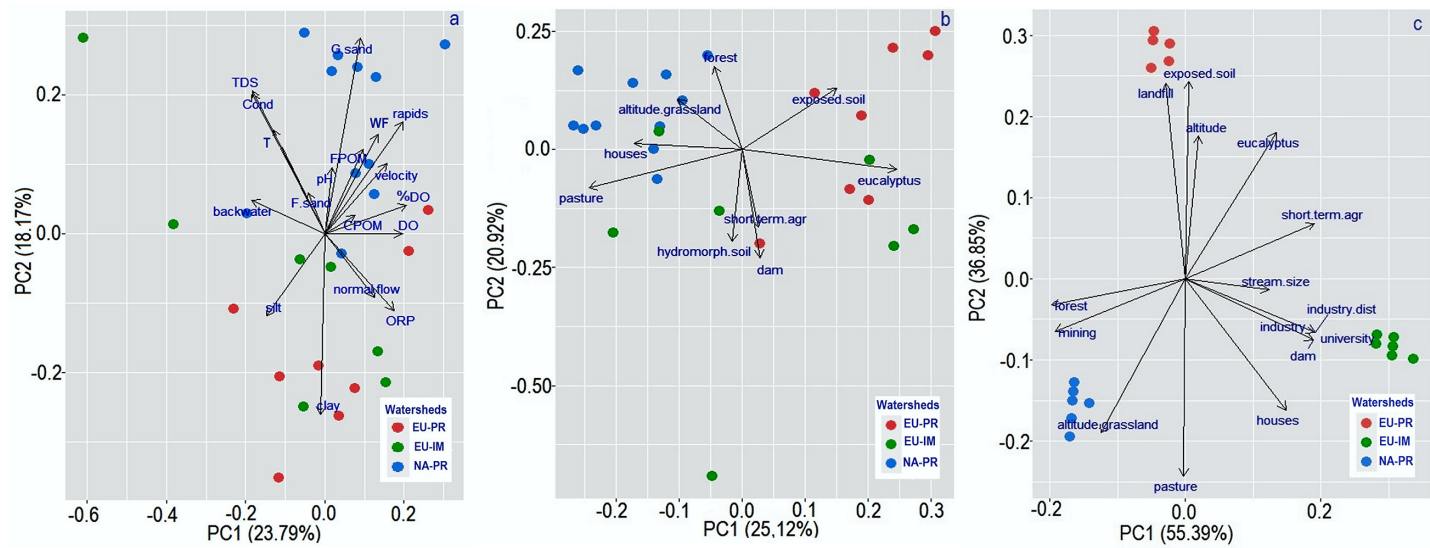

Figure 2. Principal Components Analysis of the local scale of each watershed (a), land uses in the surrounding streams in a buffer of 100 meters radius (riparian scale) (b) and land uses in the watershed as a whole (watershed scale) (c). PC1 = Principal Component 1; PC2 = Principal Component 2; EU-IM = Eucalyptus impacted watershed (without conservation practices); EU-PR = eucalyptus preserved watershed (with conservation practices); NA-PR = native and preserved watershed; $\mathrm{CPOM}=$ coarse particulate organic matter; $\mathrm{FPOM}=$ fine particulate organic matter; $\mathrm{ORP}=$ redox potential; TDS = total dissolved solids; Cond = Electrical Conductivity; WF = Water flow; DO = Dissolved oxygen; $\% \mathrm{DO}=$ dissolved oxygen percent; $\mathrm{T}=$ Water temperature; F.sand $=$ thin sand; G.Sand= course sand. 


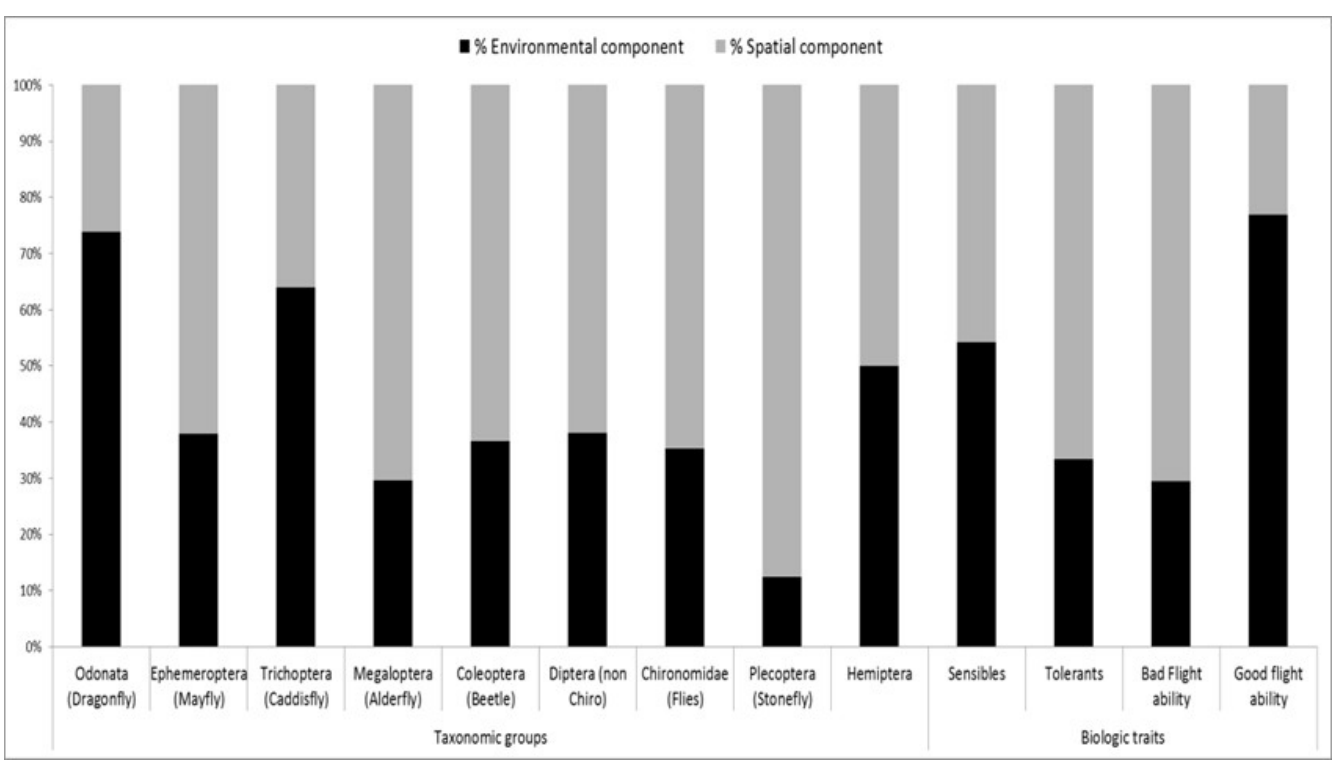

Figure 3. Proportional importance of the spatial and environmental components in the metacommunities grouped in taxonomic groups and deconstructed by biological traits. Proportions are relating Adj $\mathrm{R}^{2}$ values from redundancy analysis using environmental and spatial matrices as explanatory factors.

Table 1. Percentages of explanation with significant variables $(\mathrm{p}<0.001)$ selected on multiple scales (limnological, riparian and watershed) of influence on the taxonomic groups for Poços de Caldas Plateau.

\begin{tabular}{|c|c|c|c|c|c|c|}
\hline \multirow[b]{2}{*}{ Taxonomic Groups } & \multicolumn{6}{|c|}{ Environmental explicability percentages in different scales } \\
\hline & $\begin{array}{c}\text { Selected } \\
\text { variables } \\
\text { local scale }\end{array}$ & $\begin{array}{c}\text { Selected } \\
\text { variables } \\
\text { riparian } \\
\text { scale }\end{array}$ & $\begin{array}{c}\text { Selected } \\
\text { variables } \\
\text { watershed } \\
\text { scale }\end{array}$ & $\begin{array}{l}\text { Selected } \\
\text { vectors } \\
\text { spatial } \\
\text { (PCNMs) }\end{array}$ & $\begin{array}{c}\text { (\%) } \\
\text { Explicability } \\
\text { (Rda-Partial) } \\
\text { environmental } \\
\text { component }\end{array}$ & $\begin{array}{c}(\%) \\
\text { Explicability } \\
\text { (Rda-Partial) } \\
\text { spatial } \\
\text { component } \\
\text { (PCNMs) }\end{array}$ \\
\hline $\begin{array}{l}\text { ODONATA } \\
\text { (Dragonfly) }\end{array}$ & $\begin{array}{c}\text { Redox } \\
\text { Potential and } \\
\text { Rapids }\end{array}$ & $\begin{array}{c}\text { Dam, altitude } \\
\text { grassland } \\
\text { and Forest }\end{array}$ & n.s.v. & $\begin{array}{l}\text { PCNM1, } \\
\text { PCNM4 }\end{array}$ & 31 & 11 \\
\hline $\begin{array}{l}\text { CHIRONOMIDAE } \\
\text { (Flies) }\end{array}$ & n.s.v. & Forest & n.s.v. & $\begin{array}{l}\text { PCNM1, } \\
\text { PCNM2 }\end{array}$ & 6 & 11 \\
\hline $\begin{array}{l}\text { TRICHOPTERA } \\
\text { (Caddisfly) }\end{array}$ & n.s.v. & $\begin{array}{l}\text { Altitude } \\
\text { grassland }\end{array}$ & n.s.v. & PCNM2 & 16 & 9 \\
\hline $\begin{array}{l}\text { COLEOPTERA } \\
\text { (Beetle) }\end{array}$ & $\begin{array}{l}\text { Ph, Normal } \\
\text { Flow }\end{array}$ & n.s.v. & n.s.v. & $\begin{array}{l}\text { PCNM6, } \\
\text { PCNM7 }\end{array}$ & 11 & 19 \\
\hline DIPTERA (Flies) & Backwater & $\begin{array}{l}\text { Short term } \\
\text { agriculture }\end{array}$ & n.s.v. & $\begin{array}{l}\text { PCNM1, } \\
\text { PCNM2 }\end{array}$ & 8 & 13 \\
\hline $\begin{array}{l}\text { EPHEMEROPTERA } \\
\text { (Mayfly) }\end{array}$ & Normal Flow & Dam & n.s.v. & $\begin{array}{l}\text { PCNM1, } \\
\text { PCNM3, } \\
\text { PCNM4, } \\
\text { PCNM5, } \\
\text { PCNM8 }\end{array}$ & 22 & 36 \\
\hline $\begin{array}{l}\text { PLECOPTERA } \\
\text { (Stonefly) }\end{array}$ & n.s.v. & n.s.v. & n.s.v. & PCNM2 & 1 & 7 \\
\hline HEMIPTERA & n.s.v. & n.s.v. & n.s.v. & n.s.v. & 1 & 1 \\
\hline $\begin{array}{l}\text { MEGALOPTERA } \\
\text { (Alderfly) }\end{array}$ & n.s.v. & Pasture & n.s.v. & $\begin{array}{l}\text { PCM7, } \\
\text { PCNM9 }\end{array}$ & 13 & 31 \\
\hline Tolerants & n.s.v. & Forest & n.s.v. & $\begin{array}{l}\text { PCNM1, } \\
\text { PCNM2 }\end{array}$ & 5 & 10 \\
\hline Sensibles & $\mathrm{Ph}$ & $\begin{array}{c}\text { Dam, } \\
\text { Residencial }\end{array}$ & n.s.v. & $\begin{array}{l}\text { PCNM1, } \\
\text { PCNM3 }\end{array}$ & 13 & 11 \\
\hline Good flight ability & $\begin{array}{c}\text { Water } \\
\text { Temperature }\end{array}$ & $\begin{array}{l}\text { Altitude } \\
\text { grassland }\end{array}$ & Altitude & PCNM2 & 10 & 3 \\
\hline Bad flight ability & n.s.v. & Forest & n.s.v. & $\begin{array}{l}\text { PCNM1, } \\
\text { PCNM2 }\end{array}$ & 5 & 12 \\
\hline
\end{tabular}

n.s.v. $=$ no significant variable. 
were those that most closely highlight the data, either alone or together. The taxa that responded to the local limnological variables were Odonata, Coleoptera, Diptera (general) and Ephemeroptera, while Chironomidae, Trichoptera, Plecoptera, Hemiptera, and Megaloptera did not respond significantly to them. Regarding the biological traits analyzed, the animals classified as tolerant and with less potential for the flight were not significantly related to any measured limnological variable, whereas those sensitive and with good potential for the flight were significantly related to the $\mathrm{pH}$ and water temperature. We also noticed that the four synthesized groups (tolerant, sensitive, good flying, and bad flying) were related, at least, to a vector of the spatial component matrix.

In general, there was a greater correlation of all the taxonomic groups analyzed and also grouped by functional traits with the variables of the riparian scale (buffer 100 meters). Natural formations such as altitude grassland and forests were decisive for Odonata, Chironomidae, Trichoptera, the Tolerants, good and bad flying, while anthropogenic uses such as dam, short term agriculture, and pastures were determinant for Odonata (also), Diptera, Ephemeroptera, and the sensitive ones. Coleoptera, Plecoptera, and Hemiptera did not show significant responses to variables in the riparian scale (buffer 100 meters).

The variables on the drainage basin scale by themselves were not significant to explain the variability of the data. Apparently, these variables have been overlapping by the spatial component (distance among streams) and the variables of the riparian scale as we consider them as related information (covering the riparian zone and coverage in the watershed) and with complementary effects. It is interesting to note that the only element significantly selected by the model in the watershed basin scale was altitude, over the groups with good flight ability, although some variables were also important in this scale. However, as they were collinear at altitude they were removed before the model adjusted.

There was no significant correlation between the spatial and environmental components neither for the taxonomic groups $(\mathrm{p}=0.194)$ nor the taxon deconstructed in biological traits $(\mathrm{p}=0.100)$.

\section{Discussion}

The taxonomic and functional groups showed different responses to environmental and spatial variables. This showed that not only the environmental filtering mechanisms act on the analyzed metacommunities, but also the spatial structuring. As demonstrated by Heino et al. (2015a) the metacommunity structuring processes may vary depending on the geographical areas, the dispersive potential of the analyzed group, and also the spatial distance. Here we find that there is a lot of variation in the taxonomic groups regarding the environmental and spatial effect, but when these were grouped according to attributes considered relevant for the assembly of metacommunities (sensitivity to environmental impacts and flight potential) the response was according to predictions. Sensitive groups were filtered by local and regional abiotic variables and groups formed by good flyers were weakly related to geographical distance, indicating that they are able to colonize the appropriate sites regardless of the spatial extent of the Poços de Caldas Plateau which in this case is approximately $34 \mathrm{~km}$ in a straight line among streams furthest from each other. It is important to highlight that the watersheds analyzed showed very different land uses and the interaction among these landscape components at different scales seemed to have a direct influence on the limnological (local) attributes selected in the adjusted model, for both characterizations, taxonomic and functional. As shown by Allan (2004), Sensolo et al. (2012), Alemu et al. (2017) and Dala-Corte et al.(2020), the components of the landscape matrix can act alone or jointly on aquatic biota, which apparently also can be evidenced in our data. We realized that there was an interaction among the variables at the different scales analyzed, and these can have been the necessary local triggers for the dispersive processes in these metacommunities.

The taxonomic groups that responded most strongly to the pure environmental component were Trichoptera and Odonata, probably because of their natural history that controls their environmental requirements and because they have a relatively good dispersion ability considering the studied spatial extent and the insularity of the Plateau of Poços of Caldas. Tricopterans did not correlate specifically with any measured limnological variable (local scale) as we have predicted. Many species in this group are sensitive to environmental variations and need streams with fast flowing waters due to their respiration strategies and inability to swim actively (Poff et al., 2006). They are strongly dependent on the surroundings matrix for obtaining resources for the construction of their shelters (Saito et al., 2015a), mainly in headwater streams with expected 
low productivity. We emphasize that within Trichoptera Order there are species with a good flying ability (in lesser quantity) and those with little flying ability (Poff et al., 2006; Padial et al., 2014). Due to these discordant traits within taxonomic groups, we recorded more coherent responses by analyzing the structure of these metacommunities from their functional grouping, determined by biological traits than purely by phylogenetic taxonomic grouping.

Odonata, which are known to be sensitive and have the good flying ability, also responded more strongly to the pure environmental component like limnological environmental variables (redox potential and presence of rapids) and regional variables like the presence of dams and the presence of forested areas and altitude grassland surroundings streams. Although considered more sensitive to environmental changes than Chironomidae and other Diptera, some Odonata can persist in impacted matrices, since they have the capacity to actively search for microhabitats with better environmental conditions (Dolný et al., 2014). However, the conservation of these sites (streams surroundings) is a key factor for the local limnological quality, and when there is a loss of this minimum necessary limnological quality, it is possible that adults would cross the dispersive geographical barriers in search for new reproductive sites. This highlights the synergistic effects required at different scales for their decision to establish or disperse in the landscape matrix, mainly because Odonata has a good flying ability (Padial \& Ceschin, et al., 2014; Saito et al., 2015b), demonstrating to have a trade-off adjusted evolutionarily for this purpose. Perhaps this characteristic is one of the most important in the maintenance and success of the most ancient phylogenetically clades, such as Odonata, throughout the evolutionary process and changes in the environment. Thus, in our study region with a small spatial scale, it is possible that Odonata communities are being structured mainly by environmental filtering processes (species sorting) while Trichoptera by environmental filtering, but also by dispersive processes.

Ephemeroptera was the taxon that showed greater response to the two components (environmental and spatial). The strong correlation with space is consistent with the results obtained by Costa et al. (2014), who also analyzed metacommunities of ephemerids in a similar biome to ours, on altitude streams in the Atlantic Forest. However, our results are contrary to those recorded by Shimano et al.
(2013) in which the pure environmental component was more determinant in the structuring processes of the ephemerids metacommunities analyzed on a region with lower altitudes and located in transition zones between Cerrado and Amazon biomes. This suggests finer biological adjustments modeled over the evolutionary history of taxa in a differentiated and appropriate way to their geographic regions and their specific characteristics (Heino et al., 2016). In this sense, we suggest that metacommunity processes are dependent on analyzed scales and characteristics of the study regions, such as landscape connectivity, altitude, geographical barriers, in addition to other possible physiographic elements. Especially in our study region, these elements are very different, such as the period and the process of geological formation $(-75 \mathrm{~m} . \mathrm{a})$ that culminated in high altitudes, the isolation of streams on the inner edge of the "volcanic caldera", the high rainfall indexes, beyond the seasonal winds. These climatic elements can act together with other variables and determine the metacommunity patterns of the regional biota.

The landscape matrix is a relevant component, considering that the taxonomic groups have different dispersive ability (Bilton et al., 2001; Poff et al., 2006; Saito et al., 2015b) and not all have equal chances of colonization and persistence (Sensolo et al., 2012). However, it is possible that the effects caused by land use variables (drainage basin scale) have been overlapped by the pure spatial component and therefore, not directly influenced our results. This does not mean that they are not acting on the deconstructed groups, but maybe only that can just not be captured by the model used. Thus, it is possible to infer that environmental gradients such as those determined, for example by altitude, can also act on larger geographic scales, such as those of the watershed basin and its geographical location (Heino et al., 2015b). In this case, we realized that the altitude was the only element of the watershed scale that was significantly related to the good flyers groups, although this functional group apparently has more decision autonomy between settling or dispersing. Furthermore, it is possible that other elements of the watershed scale are also involved and correlating with biological data, but due to the presented multicollinearity, they were excluded from the analyzes (e.g. altitude, landfill and exposed soil), demonstrating that correlative studies have limitations to determine the relative importance of components analyzed, even using appropriate statistical techniques (e.g. variation partitioning). 
Although we did not detect a direct and significant correlation between both components analyzed (space and environment), the possible trade-off relationships were more evident when we analyzed the biological traits. Thus, metacommunities composed of the bad flyers and tolerant insects are more structured by spatial effects, since both associated biological features overlap the environmental filtration, guaranteeing the persistence of these groups. On the other hand, and also as predicted, groups with good flying ability are less influenced by spatial distances and show a greater environmental signature. Similar results were recorded by Bie et al. (2012), Heino (2013), and Padial et al.(2014) in which biological traits were key elements in structuring metacommunities. The ability of adult winged and good dispersants to explore new areas emphasizes the importance of spatial and environmental components, ensuring greater possibilities for persistence (Bilton et al., 2001).

In this sense and considering a conservationist perspective, groups considered sensitive become the most vulnerable to environmental changes in landscape scales because they have an equally strong environmental and spatial signature. Thus, we can perceive the joint action between biogeographic processes and the natural evolutionary history of the groups in the determination of metacommunities, and only taxonomic resolutions may not be sufficiently accurate tools for the definition of structuring in aquatic invertebrate metacommunities and conservation of these groups.

Finally, besides the multiple responses recorded in this study, we highlight the importance of a compartmentalized approach to environmental variables when studying metacommunity patterns, especially in altitude streams. Understanding how local and regional components act on biodiversity is extremely important for conservation programs, especially considering that often the Brazilian law aspects do not comply with their function of preserving continental aquatic ecosystems (Dala-Corte et al., 2020).

\section{Acknowledgements}

The authors would like to thank the Coordenação de Aperfeiçoamento de Pessoal de Nível Superior - Brazil (CAPES); The Programa de Pós-graduação em Ecologia e Recursos Naturais - PPGERN/UFSCAR; the Instituto Federal de Educação, Ciência e Tecnologia do Sul de Minas - IFSULDEMINAS; The Universidade
Federal de Alfenas (UNIFAL-MG); taxonomists Fábio Batagini Quinteiro, Humberto Fonseca Mendes, Rhainer Guillermo Nascimento Ferreira, and Susana Trivinho-Strixino for helping the taxonomic identification of biological material.

\section{References}

ALBERTI, H.L.C. Caracterização fisiográfica e avaliação hidrológica na bacia do Ribeirão das Antas, Planalto de Poços de Caldas, MG [Dissertaçáo de Mestrado em Geociências]. Campinas: Universidade Estadual de Campinas, 2008.

ALEMU, T., BAHRNDORFF, S., HUNDERA, K., ALEMAYEHU, E. and AMBELU, A. Effect of riparian land use on environmental conditions and riparian vegetation in the east African highland streams. Limnologica, 2017, 66(1), 1-11. http:// dx.doi.org/10.1016/j.limno.2017.07.001.

ALLAN, J.D. and CASTILLO, M.M. Stream ecology structure and function of running waters. Michigan: Chapman \& Hall, 1995. http://dx.doi. org/10.1007/978-94-011-0729-7.

ALLAN, J.D. Landscape and riverscape: the influence of land use on stream ecosystems. Annual Review of Ecology Evolution and Systematics, 2004, 35(1), 257-284. http://dx.doi.org/10.1146/annurev. ecolsys.35.120202.110122.

BENETTI, C.J., CUETO, J.A.R. and FIORENTIN, G.L. Gêneros de Hydraphaga (Coleoptera: Dytiscidae, Gyrinidae, Haliplidae, Noteridae) citados para o Brasil, com chaves. Biota Neotropica, 2003, 3(1), 1-20. http://dx.doi.org/10.1590/S167606032003000100010.

BIE, T., MEESTER, L., BRENDONCK, L., MARTENS, K., GODDEERIS, B., ERCKEN, D., HAMPEL, H., DENYS, L., VANHECKE, L., GUCHT, K., WICHELEN, J., VYVERMAN, W. and DECLERCK, S.A.J. R Body size and dispersal mode as key traits determining metacommunity structure of aquatic organisms. Ecology Letters, 2012, 15(7), 740-747. http://dx.doi.org/10.1111/j.14610248.2012.01794.x. PMid:22583795.

BILTON, D.T., FREELAND, J.R. and OKAMURA, B. Dispersal in freshwater invertebrates. Annual Review of Ecology and Systematics, 2001, 32(1), 159-181. http://dx.doi.org/10.1146/annurev. ecolsys.32.081501.114016.

BORCARD, D. and LEGENDRE, P. All-scale spatial analysis of ecological data by means of principal coordinates of neighbour matrices. Ecological Modelling, 2002, 153(1-2), 51-68. http://dx.doi. org/10.1016/S0304-3800(01)00501-4.

BORCARD, D., GILLET, F. and LEGENDRE, P. Numerical ecology with R.1. New York: Springer, 2011. http://dx.doi.org/10.1007/978-1-44197976-6. 
BORCARD, D., LEGENDRE, P. and DRAPEAU, P. Partialling out the spatial component of ecological variation. Ecology, 1992, 73(3), 1045-1055. http:// dx.doi.org/10.2307/1940179.

BORCARD, D., LEGENDRE, P., AVOIS-JACQUET, C. and TUOMISTO, H. Dissecting the spatial structure of ecological data at multiple scales. Ecology, 2004, 85(7), 1826-1832. http://dx.doi. org/10.1890/03-3111.

BRAUN, B.M., SALVARREY, A.V.B., KOTZIAN, C.B., SPIES, M.R. and PIRES, M.M. Diversity and distribution of riffle beetle assemblages (Coleoptera, Elmidae) in montane rivers of Southern Brazil. Biota Neotropica, 2014, 14(2), 1-11. http://dx.doi. org/10.1590/1676-060320140615183046.

CALLISTO, M., BARBOSA, F.A. and MORENO, P. Aplicação de um protocolo de avaliação rapida da diversidade de habitats em atividades de ensino e pesquisa (MG-RJ). Acta Limnologica Brasiliensia, 2002, 14(1), 91-98.

COSTA, D.S.M., BRANCO, C.C.Z. and BISPO, P.D.C. O Papel dos Fatores Ambientais e Espaciais Sobre a Fauna de Ephemeroptera (Insecta) em Riachos de Mata Atlântica. EntomoBrasilis, 2014, 7(2), 86-92. http://dx.doi.org/10.12741/ebrasilis. v7i2.368.

DALA-CORTE, R.B., MELO, A.S., SIQUEIRA, T., BINI, L.M., MARTINS, R.T., CUNICO, A.M., PES, A.M., MAGALHÃES, A.L.B., GODOY, B.S., LEAL, C.G., MONTEIRO-JÚNIOR, C.S., STENERT, C., CASTRO, D.M.P., MACEDO, D.R., LIMA-JUNIOR, D.P., GUBIANI, É.A., MASSARIOL, F.C., TERESA, F.B., BECKER, F.G., SOUZA, F.N., VALENTE-NETO, F., SOUZA, F.L., SALLES, F.F., BREJÃO, G.L., BRITO, J.G., VITULE, J.R.S., SIMIÃO-FERREIRA, J., DIAS-SILVA, K., ALBUQUERQUE, L., JUEN, L., MALTCHIK, L., CASATTI, L., MONTAG, L., RODRIGUES, M.E., CALLISTO, M., NOGUEIRA, M.A.M., SANTOS, M.R., HAMADA, N., PAMPLIN, P.A.Z., POMPEU, P.S., LEITÃO, R.P., RUARO, R., MARIANO, R., COUCEIRO, S.R.M., ABILHOA, V., OLIVEIRA, V.C., SHIMANO, Y., MORETTO, Y., SÚAREZ, Y.R. and ROQUE, F.O. Thresholds of freshwater biodiversity in response to riparian vegetation loss in the Neotropical region. Journal of Applied Ecology, 2020, 5, 1-12. http://dx.doi.org/10.1111/13652664.13657.

DOLNÝ, A., HARABIŠ, F. and MIŽIČOVÁ, H. Home Range, movement, and distribution patterns of the threatened dragonfly Sympetrum depressiusculum (Odonata: Libellulidae): a thousand times greater territory to protect? PLoS One, 2014, 9(7), e100408. http://dx.doi.org/10.1371/journal.pone.0100408. PMid:25006671.
DOMINGUEZ, E.F. and FERNÁNDEZ, R. H. Macroinvertebrados bentónicos sudamericanos: sistemática y biologica. Tucuman: Fund. Miguel Lillo, 2009.

DRAY, S., LEGENDRE, P. and PERES-NETO, P. Spatial modelling: a comprehensive framework for principal coordinate analysis of neighbour matrices (PCNM). Ecological Modelling, 2006, 196(3-4), 483-493. http://dx.doi.org/10.1016/j. ecolmodel.2006.02.015.

EPLER, J.H. Identification manual for the Larval Chironomidae (Diptera) of North and South Carolina. Raleigh, North Carolina: North Carolina Department of Environment and Natural Resources, 2001.

FINN, D.S. and POFF, N.L. Variability and convergence in benthic communities along the longitudinal gradients of four physically similar Rocky Mountain streams. Freshwater Biology, 2005, 50(2), 243-261. http://dx.doi.org/10.1111/j.13652427.2004.01320.x.

FINN, D.S., BONADA, N., MÚRRIA, C. and HUGHES, J.M. Small but mighty: headwaters are vital to stream network biodiversity at two levels of organization. Freshwater Science, 2011, 30(4), 963-980.

FRISSELL, C.A., LISS, W.J., WARREN, C.E. and HURLEY, M.D. A hierarchical framework for stream habitat classification: viewing streams in a watershed context. Environmental Management, 1986, 10(2), 199-214. http://dx.doi.org/10.1007/BF01867358.

FROEHLICH, C.G. Checklist dos Plecoptera (Insecta) do Estado de Sáo Paulo, Brasil. Biota Neotropica, 2011, 11(1), 601-606, Supplement 1. http://dx.doi. org/10.1590/S1676-06032011000500026.

HAMADA, N., NESSIMIAN, J.L. and BARBOSA, R. Insetos aquáticos na Amazônia brasileira: taxonomia, biologia e ecologia. Manaus: INPA, 2014.

HECKMAN, C.W. Encyclopedia of South American Aquatic Insects: Odonata Anisopera. Netherlands: Springer, 2006.

HECKMAN, C.W. Encyclopedia of South American Aquatic Insects: Odonata Zygoptera. Netherlands: Springer, 2008. http://dx.doi.org/10.1007/978-14020-8176-7.

HEINO, J. Does dispersal ability affect the relative importance of environmental control and spatial structuring of littoral macroinvertebrate communities? Oecologia, 2013, 171(4), 971-980. http://dx.doi.org/10.1007/s00442-012-2451-4. PMid:22961400.

HEINO, J., MELO, A.S., SIQUEIRA, T., SOININEN, J., VALANKO, S. and BINI, L.M. Metacommunity organisation, spatial extent and dispersal in aquatic systems: patterns, processes and prospects. Freshwater Biology, 2015a, 60(5), 845-886. http://dx.doi. org/10.1111/fwb.12533. 
HEINO, J., NOKELA, T., SOININEN, J., TOLKKINEN, M., VIRTANEN, L. and VIRTANEN, R. Elements of metacommunity structure and community environment relationships in stream organisms environment. Freshwater Biology, 2015b, 60(5), 973-988. http://dx.doi.org/10.1111/ fwb. 12556.

HEINO, J., SOININEN, J., ALAHUHTA, J., LAPPALAINEN, J. and VIRTANEN, R. Metacommunity ecology meets biogeography: effects of geographical region, spatial dynamics and environmentalfiltering on community structure in aquatic organisms. Oecologia, 2016, 183(1), 121137. http://dx.doi.org/10.1007/s00442-016-3750-y. PMid:27714463.

HEINO, J., ALAHUHTA, J., ALA-HULKKO, T., ANTIKAINEN, H., BINI, L.M., BONADA, N., DATRY, T., ERÖS, T., HJORT, J., KOTAVAARA, O., MELO, A.S. and SOININEN, J. Integrating dispersal proxies in ecological and environmental research in the freshwater realm. Environmental Reviews, 2017, 25(3), 334-349. http://dx.doi. org/10.1139/er-2016-0110.

JUNQUEIRA, V.M. and CAMPOS, S.C.M. Adaptation of the "BMWP" method for water quality evaluation to Rio das Velhas Watershed (Minas Gerais, Brazil). Acta Limnologica Brasiliensia, 1998, 10, 125-135.

LECCI, L.S. and FROEHLICH, C.G. Guia on-line: identificação de larvas de insetos aquáticos do Estado de São Paulo: Plecoptera [online]. Ribeirão Preto: Laboratório de Entomologia Aquática, Faculdade de Filosofia, Ciências e Letras de Ribeirão Preto, Universidade de São Paulo Campus de São Carlos, 2007 [viewed 15 June 2017]. Available from: http:// sites.ffclrp.usp.br/aguadoce/Guia_online/Guia_ identifica\%C3\%A7\%C3\%A3o_larvas_Plecoptera. pdf

LEGENDRE, P. and GALLAGHER, E.D. Ecologically meaningful transformations for ordination of species data. Oecologia, 2001, 129(2), 271-280. http://dx.doi. org/10.1007/s004420100716. PMid:28547606.

LEIBOLD, M.A., HOLYOAK, M., MOUQUET, N., AMARASEKARE, P., CHASE, J.M., HOOPES, M.F., HOLT, R.D., SHURIN, J.B., LAW, R., TILMAN, D., LOREAU, M. and GONZALEZ, A. The metacommunity concept: a framework for multi-scale community ecology. Ecology Letters, 2004, 7(7), 601-613. http://dx.doi.org/10.1111/j.14610248.2004.00608.x.

MALMQVIST, B. How does wing length relate to distribution patterns of stoneflies (Plecoptera) and mayflies (Ephemeroptera)? Biological Conservation, 2000, 93(2), 271-276. http://dx.doi.org/10.1016/ S0006-3207(99)00139-1.

MARIANO, R. and FROEHLICH, C.G. Ephemeroptera. In: Universidade de São Paulo. Guia on-line: identificação de larvas de insetos aquáticos do Estado de São Paulo [online]. Ribeirão Preto: Laboratório de Entomologia Aquática, Faculdade de Filosofia, Ciências e Letras de Ribeirão Preto, Universidade de São Paulo, 2007. [viewed 18 June 2017]. Available from: http://sites.ffclrp.usp.br/aguadoce/guiaonline

MERRITT, R.W. and CUMMINS, K.W. An introduction to the aquatic insects of North America. Dubuque: Kendall, Hunt, 1996.

MICHAT, M.C., ARCHANGELSKY, M. and BACHMANN, A.O. Generic keys for the identifi cation of larval Dytiscidae from Argentina (Coleoptera: Adephaga). Revista de la Sociedad Entomológica Argentina, 2008, 67, 3-4.

MORAES, F.T. and JIMÉNEZ-RUEDA, J.R. Fisiografia da região do planalto de Poços de Caldas, MG/ SP. Revista Brasileira de Geociencias, 2008, 38(1), 196-208. http://dx.doi.org/10.25249/03757536.2008381196208.

MORAES, F.T. Zoneamento geoambiental do planalto de Poços de Caldas, MG/SP a partir de análise fisiográfica e pedoestratigráfica [Tese de Doutorado em em Geociências e Meio Ambiente]. Rio Claro: Universidade Estadual Paulista, 2007.

MUGNAI, R., NESSIMIAN, J.L. and BAPTISTA, D.F. Manual de identificação de macroinvertebrados aquáticos do Estado do Rio de Janeiro. Rio de Janeiro: Technical Books, 2010.

OKSANEN, J., BLANCHET, F.G., FRIENDLY, M., KINDT, R., LEGENDRE, P., MCGLINN, D., MINCHIN, P.R., O'HARA, R.B., SIMPSON, G.L., SOLYMOS, P., HENRY, M., STEVENS, H., SZOECS, E. and WAGNER, H. Vegan: Community Ecology Package. $R$ package version 2.4-3 [online]. Vienna: R Foundation for Statistical Computing, 2017 [viewed 15 June 2017]. Available from: https: //CRAN.R-project.org/package=vegan

PADIAL, A., CESCHIN, F., DECLERCK, S.A.J., MEESTER, L., BONECKER, C.C., LANSACTÔHA, F.A., RODRIGUES, L., RODRIGUES, L.C., TRAIN, S., VELHO, L.F. and BINI, L.M. Dispersal ability determines the role of environmental, spatial and temporal drivers of metacommunity structure. PLoS One, 2014, 9(10), e111227. http://dx.doi.org/10.1371/journal.pone.0111227. PMid:25340577.

POFF, L.N., OLDEN, J.D., VIEIRA, N.K.M., FINN, D.S., SIMMONS, M.P. and KONDRATIEFF, B.C. Functional trait niches of North American lotic insects: traits-based ecological applications in light of phylogenetic relationships. Journal of the North American Benthological Society, 2006, 25(4), 730-755. http://dx.doi.org/10.1899/08873593(2006)025[0730:FTNONA]2.0.CO;2.

R CORE TEAM. $R$ : a language and environment for statistical computing. Vienna: R Foundation for Statistical Computing, 2017. 
RAMÍREZ, A. Capitulo 5: Odonata. Revista de Biología Tropical, 2010, 58(4), 97-136.

REYNOLDS, C.S., HUSZAR, R.V., KRUK, C., NASELLI-FLORES, L. and MELO, S. Towards a functional classification of the freshwater phytoplankton. Journal of Plankton Research, 2002, 200224(5), 417-428. http://dx.doi.org/10.1093/ plankt/24.5.417.

SAITO, V.S., SIQUEIRA, T. and FONSECAGESSNER, A.A. Should phylogenetic and functional diversity metrics compose macroinvertebrate multimetric indices for stream biomonitoring? Hydrobiologia, 2015a, 745(1), 167-179. http:// dx.doi.org/10.1007/s10750-014-2102-3.

SAITO, V.S., SOININEN, J., FONSECA-GESSNER, A.A. and SIQUEIRA, T. Dispersal traits drive the phylogenetic distance decay of similarity in neotropical stream metacommunities. Journal of Biogeography, 2015b, 42(11), 2101-2111. http:// dx.doi.org/10.1111/jbi.12577.

SENSOLO, D., HEPP, L.U., DECIAN, V. and RESTELLO, R.M. Influence of landscape on assemblages of Chironomidae in Neotropical streams. International Journal of Limnology, 2012, 48(4), 391-400. http://dx.doi.org/10.1051/limn/2012031.

SHIMANO, Y., JUEN, L., SALLES, F.F., NOGUEIRA, D.S. and CABETTE, H.S.R. Environmental and spatial processes determining Ephemeroptera (Insecta) structures in tropical streams. Annales de Limnologie - International. Journal of Limnology, 2013, 49(1), 31-41. http://dx.doi.org/10.1051/ $\operatorname{limn} / 2013036$.

SHURIN, J.B., COTTENIE, K. and HILLEBRAND, H. Spatial autocorrelation and dispersal limitation in freshwater organisms. Oecologia, 2009, 159(1), 151 159. http://dx.doi.org/10.1007/s00442-008-1174-z. PMid:18941791.

SIQUEIRA, T., BINI, L.M., ROQUE, F.O. and COTTENIE, K. A metacommunity framework for enhancing the effectiveness of biological monitoring strategies. PLoS One, 2012, 7(8), e43626. http://dx.doi.org/10.1371/journal.pone.0043626. PMid:22937068.
SPRINGER, M. Capítulo 7 Trichoptera. Revista de Biología Tropical, 2010, 58(4), 151-198.

STRAHLER, A.N. Quantitative analysis of watershed geomorphology. Transactions - American Geophysical Union, 1957, 38(6), 913-920. http://dx.doi. org/10.1029/TR038i006p00913.

TER BRAAK, C.A.J.O.J.F. and PRENTICE, C.I. A theory of gradient analysis. Advances in Ecological Research, 1988, 18, 271-317. http://dx.doi. org/10.1016/S0065-2504(08)60183-X.

TOBLER, W. A computer movie simulating urban growth in the Detroit region. Economic Geography, 1970, 46, 234-240. http://dx.doi.org/10.2307/143141.

TONKIN, J.D., ALTERMATT, F., FINN, D.S., HEINO, J., OLDEN, J.D., PAULS, S.U. and LYTLE, D.A. The role of dispersal in river network metacommunities: patterns, processes, and pathways. Freshwater Biology, 2017a, 63(1), 141-163. http:// dx.doi.org/10.1111/fwb.13037.

TONKIN, J.D., HEINO, J. and ALTERMATT, F. Metacommunities in river networks: the importance of network structure and connectivity on patterns and processes. Freshwater Biology, 2017b, 63(1), 1-5. http://dx.doi.org/10.1111/fwb.13045.

TRIVINHO-STRIXINO, S. Larvas de Chironomidae: guia de identificação [online]. São Carlos UFSCar, 2011 [viewed 18 June 2017]. Available from: https:// sites.google.com/site/brazilianchironomids/keys2/ trivinhostrixino2011

VANNOTE, R.L., MINSHALL, G.W., CUMMINS, K.W., SEDELL, J.R. and CUSHING, C.E. The River Continuum Concept. Canadian Journal of Fisheries and Aquatic Sciences, 1980, 37(1), 130-137. http://dx.doi.org/10.1139/f80-017.

WETZEL, R.G. and LIKENS, G.E. Limnological analyses. New York: Springer, 2000. http://dx.doi. org/10.1007/978-1-4757-3250-4.

Received: 01 February 2019 Accepted: 16 June 2020

Associate Editor: Antonio Fernando Monteiro Camargo. 


\section{Supplementary Material}

Supplementary material accompanies this paper.

Table. Deconstructed functional traits of species (tolerance and potential flight ability) according to Merrit \& Cummins (1996), Junqueira \& Campos (1998), Poff et al. (2006), Bilton et al. (2001) \& Saito et al. (2015). When definitions of the biological traits for a given taxon were not found, the same trait attributed to the majority of the other closely related members was employed, according to Poff et al. (2006).

This material is available from: https://www.labdiversidade.bio.br/profissionais/mireile-r-s/projeto-02 